\title{
A comparative analysis: Web design of Universities in Indonesian and American Countries based on CNET and Hall theory
}

\author{
Nuur Wachid Abdul Majid ${ }^{1}$, Taufik Ridwan², Bayu Rahmat Setiadi ${ }^{3}$, Heri Nurdiyanto ${ }^{4}$ \\ nuurwachid@upi.edu'1 , taufikridwan@upi.edu², bayursetiadi@gmail.com ${ }^{3}$, herinurdiyanto@gmail.com ${ }^{4}$ \\ Universitas Pendidikan Indonesia, Bandung, Indonesia ${ }^{1,2}$, \\ Universitas Sarjanawiyata Tamansiswa, Yogyakarta, Indonesia ${ }^{3}$ \\ Universitas Negeri Yogyakarta, Yogyakarta, Indonesia ${ }^{4}$
}

\begin{abstract}
The development of website-based technology can be useful in education. Universities can use web-based technology to communicate information to various fields without limitation, space and time. Universitas Pendidikan Indonesia (UPI) and American University (AU) are one of the universities that use website-based media to communicate information. The analytical methods used in the comparison are using CNET (builder) and Edward T Hall theory. Components in CNET (builder) include usability, a navigation system, graphic design, content, compatibility, loading time, function, while Hall components include animation, collectivism or individualism, product promotion values, transparency, linear vs. parallel navigation. The results are web AU looks simple with little image and content displayed. Many of the content is displayed on the main page on the web UPI, while at AU is not much; Images displayed on the web UPI further highlights the collectivity, while AU highlight individualists.
\end{abstract}

Keywords: web design analysis, web for education, CNET (Builder), Hall Theory.

\section{Introduction}

Web-based technology is an information tool that is often used by various fields, especially in the field of education [1]. Education needs a media that can be used to distribute information to users [2], [3]. Information submitted and received can be accessed anywhere, anytime, and anyone. The ease offered through the website, users can find out the latest information in the field of education and know the registration information of new students, courses offered, scholarships, and so forth. It can be accessed easily by users resulting in the number of educational websites that have been circulating on the internet. The information system is a communication of information technology, and one's activities use such technology to support operations and management [4], [5].

Websites have two types, namely dynamic and static web [6]. The fundamental differences in both types cannot be seen from either side but can be seen comprehensively [7]. The static web has the following characteristics: (a) no interaction between the visitor and the web owner is possible; (b) Static web usually uses the only HTML; (c) not using the database because no data needs to be stored and processed; and (d) Content or static web page content is provided only by web owners and seldom updated [8]. In contrast, dynamic web: (a) there is interaction between visitors with web owners such as providing comments, online transactions, forums, etc; 
(b) using web programming languages such as PHP and ASP; (c) using a database such as MySQL, Oracle, etc. to store and process data; and (d) Content updates more frequently. Content in the dynamic web can be loaded from the database so that it can vary [9], [10]. A system can be said to be good if it has been tested [11]-[13].

Web Education is a dynamic type website [14] because the information presented can be updated, deleted, and added. Web display design can also be modified by the owner's wishes [15]. Design changes can affect the number of visitors on the web [16]. Exciting design and easy-to-use navigation are one of the reasons why many visitors to the education website because it is beneficial for users in selecting some pages on the educational website. Web sites can be useful and ease in learning, but can also have negative impacts [17].

The university website is one part of the educational website. Some of the content displayed on this web usually presents information about academics, courses offered, scholarships, achievements, university alumni, etc. Content displayed varies depending on each website. Each region has its characteristics in posting content that will be included into the site [18].

Universitas Pendidikan Indonesia and American University are one of the universities engaged in education through the process of learning and teaching. Both institutions are well known to many people. Information on academic activities, campus developments and courses offered are much sought after by visitors. Therefore both universities have created media that can convey information needed by visitors [19]. It can be accessed anywhere, anytime, without any limitations of space and time. This paper will discuss the differences in the design of the university website in Indonesia and in the United States without having to feature and weaken each web [20].

\section{Analysis Methods}

The design is the most important element in a website [21], [22]. Website design greatly affects the visitor's judgment about whether or not the website is so important that a design determines its beauty and quality. Therefore, the higher the quality of mastery on web design, it can improve its quality [23]. The first step taken by the designer is to create a mockup [24]. Mockup serves as clarifying the needs that will be displayed on various types of websites. In addition, mockup can be used as communication tools with users. The design ideas can be visualized easily without having to explain orally or orally. Here is an example of mockup: 


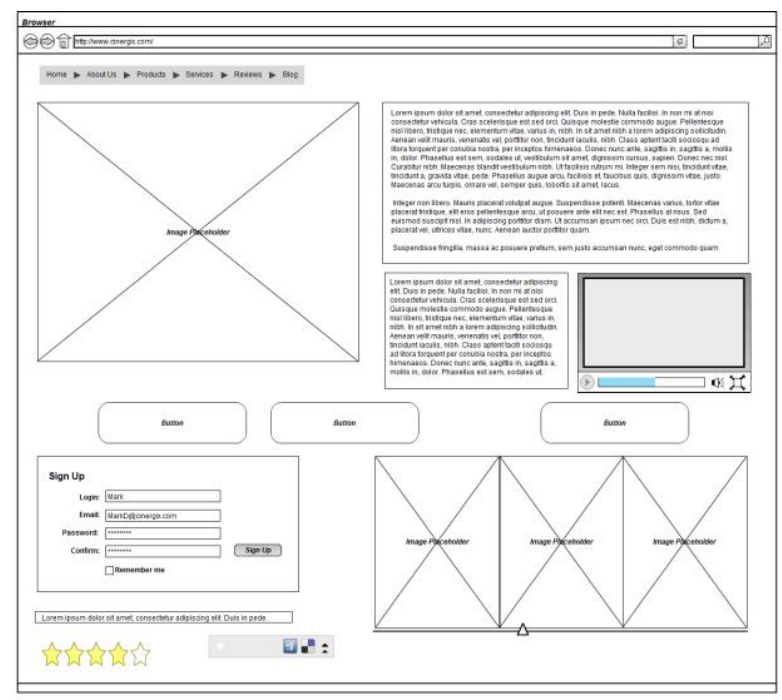

Fig. 1. Example mockup design (http://static3.creately.com)

\subsection{CNET (Builder)}

CNET Network Inc. (Center of the National d'Etudes des Telecommunication) is a telecommunication research and development center of France Telecom issued several criteria as a reference in the development of web-based application systems [25]. The criteria are as follows. Usability is can a user find a way to use the website effectively (doing things right). The navigation system can be used and understood easily by the user. Graphic design gives visitors a comfortable feel with an interesting blend of colors, graphics, typography, and layouts. Content presented on the website is very useful and needed by the user whether it is in accordance with the theme offered or not, etc. Compatibility means how wide the website can be supported by other app devices, such as on web browsers: Mozilla Firefox, Google Chrome, Opera, etc. Loading time means factors that affect loading time, such as bandwidth, internet connection, etc. The function is how well a website works from its technological aspect [26] [28].

\subsection{Hall theory}

Hall theories will focus on communicating through the relevant culture with regard to web design shown [29]. Edward T Hall has categorized this type of communication into two parts, namely low and high context [30]-[32]. Hall observes that meaning and context are closely tied to one another. Low context tends to be more complex with text-based. This results in less intuitive and slow to understand as well as less efficient [32], [33]. Low context countries are the United States, Germany, Australia, and most of Europe [34]. While the high context is the opposite of the low context, which has a feature more quickly understood and more efficient because it depends on the intuitive. But the disadvantage is that it is too slow in making media because it needs to equate perceptions between the designer and the user [33]. Countries that use the high context are Indonesia, Japan, Middle Eastern Countries, and another of Asia 
Countries [34], [35]. Here is a table of low and high context differences according to Hall theory[36].

Table 1. Comparisons of low and high context

\begin{tabular}{|c|c|c|}
\hline Comparisons & High Context Culture & Low Context Culture \\
\hline Animation & $\begin{array}{l}\text { Use of motion pictures } \\
\text { animation clips }\end{array}$ & $\begin{array}{l}\text { Use fewer images, but highlight } \\
\text { text }\end{array}$ \\
\hline $\begin{array}{l}\text { Colle } \\
\text { indivi }\end{array}$ & $\begin{array}{l}\text { The image promotes the } \\
\text { characteristic values of collectivist } \\
\text { societies. }\end{array}$ & $\begin{array}{l}\text { The image promotes the } \\
\text { characteristic values of } \\
\text { individualistic societies. }\end{array}$ \\
\hline $\begin{array}{l}\text { Product } \\
\text { promotional }\end{array}$ & $\begin{array}{llr}\text { Advertising } & \text { messages } & \text { are } \\
\text { displayed } & \text { directly } & \text { and }\end{array}$ & $\begin{array}{l}\text { Advertising messages are } \\
\text { displayed directly and rationally }\end{array}$ \\
\hline & $\begin{array}{l}\text { transformationally to create } \\
\text { emotions through images and } \\
\text { entertainment. }\end{array}$ & to display product information. \\
\hline Transparency & $\begin{array}{l}\text { Link promotes an exploratory } \\
\text { approach to website navigation } \\
\text { and process-oriented. }\end{array}$ & $\begin{array}{l}\text { The instructions are clear and } \\
\text { exaggerated concerning } \\
\text { navigation on the website and } \\
\text { goal-oriented. }\end{array}$ \\
\hline $\begin{array}{l}\text { Line: } \\
\text { navig }\end{array}$ & $\begin{array}{l}\text { There are many sidebars and } \\
\text { menus, many menus by opening a } \\
\text { new browser window for each } \\
\text { page. }\end{array}$ & $\begin{array}{l}\text { There are several sidebars and } \\
\text { menus, not many menus by } \\
\text { opening a new browser window } \\
\text { for each page. }\end{array}$ \\
\hline
\end{tabular}

\section{Results Comparison}

Analysis of university website is the website of Indonesia from the Universitas Pendidikan Indonesia (http://UPI.ac.id/) and the American University website (http://www.American.edu/). Here is the look of the website.

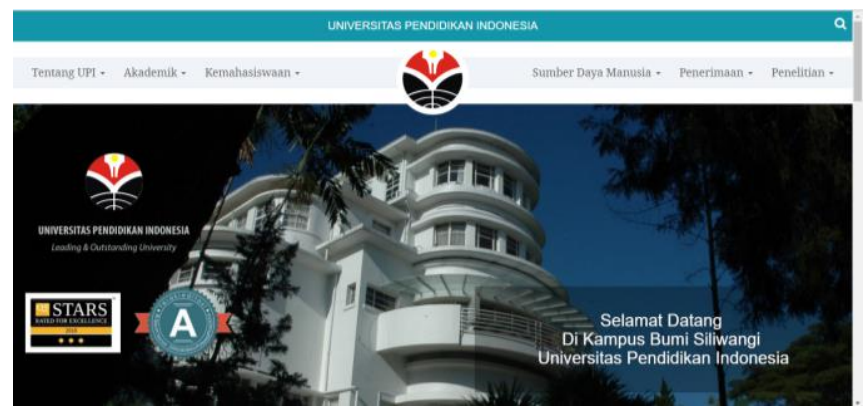

Fig. 2. Website display of Universitas Pendidikan Indonesia 


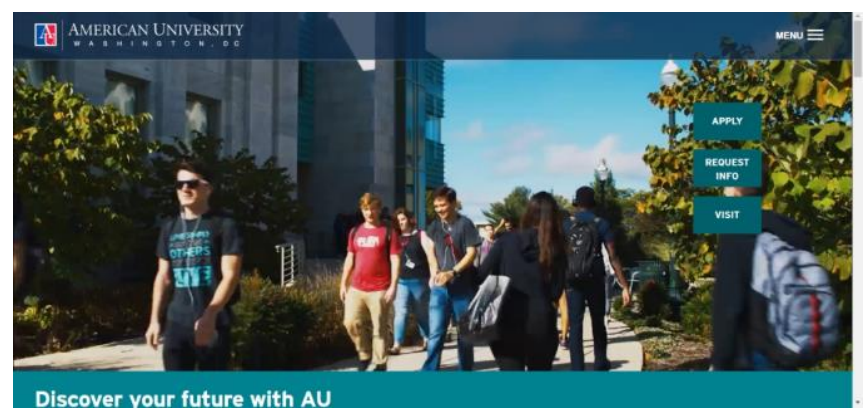

Fig. 3. Website display of American University

\subsection{Analysis based on CNET (Builder) from Jacob Nielsen}

Both websites will be compared based on CNET (Builder) from Jacob Nielsen. Below is a table on the comparison of both web.

Table 2. Comparison of web design of Universitas Pendidikan Indonesia and American University based on CNET (Builder)

\begin{tabular}{|c|c|c|}
\hline Comparisons & UPI's Website & AU's Website \\
\hline \multirow[t]{3}{*}{ Usability } & $\begin{array}{l}\text { Simple design, but too many pictures } \\
\text { and menus, this causes the website to } \\
\text { look full. }\end{array}$ & $\begin{array}{l}\text { The design is simple; the menu is } \\
\text { not too much and neatly arranged. }\end{array}$ \\
\hline & $\begin{array}{l}\text { The satisfaction level of the user is } \\
\text { good }\end{array}$ & $\begin{array}{l}\text { The satisfaction level of the user is } \\
\text { good }\end{array}$ \\
\hline & Easy to learn & Easy to learn \\
\hline \multirow[t]{3}{*}{$\begin{array}{l}\text { Navigation } \\
\text { systems }\end{array}$} & There is a language menu & $\begin{array}{l}\text { There is no language selection } \\
\text { menu }\end{array}$ \\
\hline & $\begin{array}{l}\text { The main menu is neatly arranged in } \\
\text { the header, while the submenu is on } \\
\text { the main menu and at the bottom } \\
\text { (news, motion pictures, } \\
\text { announcements, etc.) }\end{array}$ & $\begin{array}{l}\text { The main menu is placed on the } \\
\text { left side and given a green } \\
\text { background. The submenu will } \\
\text { appear when the main menu is } \\
\text { pressed. }\end{array}$ \\
\hline & All links work properly & All links work properly \\
\hline \multirow[t]{5}{*}{ Graphic design } & $\begin{array}{l}\text { The background is white, blue, and } \\
\text { gray, while the website has a white } \\
\text { background and a little blue color. }\end{array}$ & $\begin{array}{l}\text { Website background with a gray } \\
\text { color, while the web display is } \\
\text { more dominant in white and } \\
\text { slightly dark green. }\end{array}$ \\
\hline & Design looks simple & Design looks simple \\
\hline & $\begin{array}{l}\text { Logo placed in the middle along with } \\
\text { the identity of the website Universitas }\end{array}$ & $\begin{array}{l}\text { American University logo and web } \\
\text { identity are placed on the left side, }\end{array}$ \\
\hline & $\begin{array}{l}\text { Pendidikan Indonesia. Logo and } \\
\text { identity are placed above the main } \\
\text { menu. }\end{array}$ & above the menu. \\
\hline & $\begin{array}{l}\text { The header display is always moving } \\
\text { to be dynamic and fluid; this is } \\
\text { supported by motion pictures. }\end{array}$ & $\begin{array}{l}\text { The header does not move and can } \\
\text { only change when clicked on the } \\
\text { next button. }\end{array}$ \\
\hline
\end{tabular}




\begin{tabular}{|c|c|c|}
\hline Comparisons & UPI's Website & AU's Website \\
\hline Content & $\begin{array}{l}\text { Contains information on universities, } \\
\text { faculties and courses offered academic } \\
\text { activities, news updates, } \\
\text { announcements, etc. } \\
\text { Each information content always has a } \\
\text { picture as an explanation. } \\
\text { Images displayed are usually campus } \\
\text { officials, buildings, and some students. } \\
\text { Depending on the info presented. }\end{array}$ & $\begin{array}{l}\text { Contains information on } \\
\text { universities, faculties and courses } \\
\text { offered academic activities, news } \\
\text { updates, announcements, etc. } \\
\text { Each content has text only, very } \\
\text { rarely display images or video. } \\
\text { The pictures are presented with } \\
\text { more student activities. }\end{array}$ \\
\hline Compatibility & $\begin{array}{l}\text { Can run on various Browsers, like } \\
\text { Google Chrome, Mozilla Firefox, } \\
\text { Cool Novo, Flock, and Opera. } \\
\text { Can be connected to multiple social } \\
\text { networks } \\
\text { Can run on various platforms, such as } \\
\text { mobile phone, laptop (browser), tablet. }\end{array}$ & $\begin{array}{l}\text { Can run on various Browsers, like } \\
\text { Google Chrome, Mozilla Firefox, } \\
\text { Cool Novo, Flock, and Opera. } \\
\text { Can be connected to multiple } \\
\text { social networks } \\
\text { Can run on various platforms, such } \\
\text { as mobile phone, laptop (browser), } \\
\text { tablet. }\end{array}$ \\
\hline Loading Time & $\begin{array}{l}\text { Content is presented very much, so in } \\
\text { loading time is very influential on the } \\
\text { internet connection in use. }\end{array}$ & $\begin{array}{l}\text { Content that is served not too } \\
\text { much, but in loading time is } \\
\text { strongly influenced by the internet } \\
\text { connection used. }\end{array}$ \\
\hline Function & No visible data missing & No visible data missing \\
\hline
\end{tabular}

The table describes the comparison of the two websites from Indonesia represented by the web Universitas Pendidikan Indonesia and the United States represented by American University.

\subsection{Analysis based on Edward T Hall}

The United States is a country that uses the web with low context, while Indonesia uses high context [32], [34], [35]. This fundamental difference dramatically affects the media submitted by both countries. Here is a table of differences from both websites according to Hall theory.

Table 3. Comparison of web design of Universitas Pendidikan Indonesia and American University based on Edward T. Hall

\begin{tabular}{|c|c|c|}
\hline Comparisons & UPI's Website & AU's Website \\
\hline Animation & $\begin{array}{l}\text { There are many motion pictures, } \\
\text { displayed images, as well as some } \\
\text { other supporting animations. }\end{array}$ & $\begin{array}{l}\text { Few images are shown on the } \\
\text { website. }\end{array}$ \\
\hline $\begin{array}{l}\text { Kolektivisme dan } \\
\text { Individualisme }\end{array}$ & $\begin{array}{l}\text { The displayed images feature } \\
\text { collectivity, viewed from groups or } \\
\text { communities on a slideshow } \\
\text { although some pictures show a } \\
\text { person. }\end{array}$ & $\begin{array}{l}\text { Showing more images of a person } \\
\text { or individual. Can be seen there is } \\
\text { a student who focuses on the } \\
\text { computer. While in the header, } \\
\text { someone looks himself was } \\
\text { kicking the ball. }\end{array}$ \\
\hline
\end{tabular}




\begin{tabular}{lll}
\hline Comparisons & UPI's Website & AU's Website \\
\hline $\begin{array}{l}\text { Product } \\
\text { promotional } \\
\text { values }\end{array}$ & $\begin{array}{l}\text { The image presented is more } \\
\text { emphasized in the slideshows } \\
\text { under the header. Also, the picture } \\
\text { comes with a text that can be }\end{array}$ & $\begin{array}{l}\text { This natural nature shows the } \\
\text { activities undertaken at American }\end{array}$ \\
& $\begin{array}{l}\text { quickly clicked by visitors. This } \\
\text { can make visitors more interested }\end{array}$ & University. \\
in animation and images. & & \\
There is no transparency on the & There is no transparency on the \\
menu or web links. It is just that the & menu or web links. It is just that \\
menu if brought closer will change & $\begin{array}{l}\text { the menu if brought closer will } \\
\text { change to a different color. }\end{array}$ \\
& $\begin{array}{l}\text { to a different color. } \\
\text { Too many menus and sidebars on } \\
\text { the website. }\end{array}$ & $\begin{array}{l}\text { Few menus and sidebars on the } \\
\text { web. }\end{array}$ \\
\hline
\end{tabular}

\section{Conclusions}

The results of comparative analysis on both websites from Universitas Pendidikan Indonesia and American University can be drawn some conclusions, among others:

1. Web of Universitas Pendidikan Indonesia more images and content are displayed, so that looks crowded on the website. While the web of American University looks simple with little image and content displayed

2. Many contents are displayed on the main page on the internet of Universitas Pendidikan Indonesia, while at American University there is not much content displayed.

3. Images displayed on the web of Universitas Pendidikan Indonesia are more accentuated collectivity, while American University only features individualists.

\section{References}

[1] M. S. Lyashenko, "Implementation of Web-Based Technologies into Teaching and Learning Practices in the University," vol. 6, no. 3, pp. 2014-2017, 2016.

[2] A. Weinberger, I. Kollar, Y. Dimitriadis, K. M, and F. Fischer, "Technology-Enhanced Learning," Media, no. Grenoble 1, pp. 3-19, 2009.

[3] D. Buckingham, "Media education goes digital: An introduction," Learning, Media and Technology, vol. 32, no. 2. pp. 111-119, 2007.

[4] N. W. A. Majid, "Software Quality Assurance Sistem Informasi Penerimaan Siswa Baru (SIPSB) Dengan Menggunakan ISO 9126," Yogyakarta, 2013.

[5] A. Joshi, J. Meza, S. Costa, D. M. Puricelli Perin, K. Trout, and A. Rayamajih, "The role of information and communication technology in community outreach, academic and research collaboration, and education and support services (IT-CARES).," Perspect. Health Inf. Manag., vol. 10, p. 1g, 2013.

[6] S. Arafin, "Developing a dynamic website using the online website builder Weebly for Viking Fortune Oy," 2017.

[7] L. Titchkosky, M. Arlitt, and C. Williamson, "A performance comparison of dynamic Web technologies," ACM SIGMETRICS Perform. Eval. Rev., 2003.

[8] C. Fry, M. Plusch, and H. Lieberman, "Static and dynamic semantics of the Web," Spinn. 
Semant. Web Bringing World Wide Web to its Full Potential, pp. 377-401, 2003.

[9] S. Nordbotten, "INTRODUCTION TO DEVELOPMENT OF DYNAMIC Svein Nordbotten," pp. 1-159, 2007.

[10] H. Petersen, "From Static and Dynamic Websites to Static Site Generators," 2016.

[11] L. Luo, "Software testing techniques," Inst. Softw. Res. Int. Carnegie mellon Univ. Pittsburgh, $P A$, vol. 15232 , no. 1-19, p. 19, 2001.

[12] M. Utting, A. Pretschner, and B. Legeard, "A taxonomy of model-based testing approaches," Softw. Test. Verif. Reliab., vol. 22, no. 5, pp. 297-312, 2012.

[13] R. Patton, Software Testing. 2001.

[14] R. K. Kaushal and S. N. Panda, "Effective Teaching Methods and Proposed Web Libraries for Designing Animated Course Content: A Review," vol. 7, no. 2, pp. 102-106, 2016.

[15] D. E. Rosen and E. Purinton, "Website design," J. Bus. Res., vol. 57, no. 7, pp. 787-794, 2004

[16] G. Plumley, Website Design and Development 100 Questions to Ask Before Building a Website. 2010 .

[17] N. W. Abdulmajid and B. R. Setiadi, "Pemanfaatan Social Web Environment Dalam Menciptakan Student-Centered Learning Dan Peningkatan Keterampilan Siswa Pada Pembelajaran," in Seminar Nasional Universitas PGRI Yogyakarta, 2015.

[18] D. Napitupulu et al., "Analysis of Student Satisfaction Toward Quality of Service Facility," in Journal of Physics: Conference Series, 2018, vol. 954, no. 1.

[19] W. G. Ford, "Evaluating the Effectiveness of College Web Sites for Prospective Students," J. Coll. Admiss., vol. 212, no. 2001, pp. 26-31, 2011.

[20] H. Nurdiyanto, "A work-based learning model with technopreneurship," Glob. J. Eng. Educ., vol. 20, no. 1, pp. 75-78, 2018.

[21] G. Raquel, F. Carlos, and O. Carlos, "The relevance of web design for the website success : A heuristic analysis The Relevance of Web Design for the Website Success : A heuristic analysis The relevance of web design for the website success : A heuristic analysis," in CollECTeR Iberoamérica, 2018, pp. 1-13.

[22] C. Flavian, R. Gurrea, and C. Orús, "Web design: a key factor for the website success," J. Syst. Inf. Technol., vol. 11, no. 2, pp. 168-184, 2009.

[23] M. Levis, M. Brady, and M. Helfert, "Website Design Quality and Form Input Validation: An Empirical Study on Irish Corporate Websites," J. Serv. Sci. Manag., vol. 01, no. 01, pp. 91-100, 2008

[24] R. H. Hall, S. E. Watkins, and V. M. Eller, "A Model of Web Based Design for Learning," Rolla, 2002.

[25] C. Sorin, D. Jouvet, C. Gagnoulet, D. Dubois, D. Sadek, and M. Toularhoat, "Operational and experimental French telecommunication services using CNET speech recognition and text-tospeech synthesis," Speech Commun. 17, vol. 6393, no. 95, pp. 273-286, 1995.

[26] S. Hassan and F. Li, "Evaluating the usability and content usefulness of web sites: a benchmarking approach," Electron. Commer. Concepts, Methodol. Tools, Appl., vol. 3, no. June, pp. 402-421, 2008.

[27] R. Garett, J. Chiu, L. Zhang, and S. D. Young, "A Literature Review: Website Design and User Engagement.," Online J. Commun. media Technol., vol. 6, no. 3, pp. 1-14, 2016.

[28] S. Hassan and F. Li, "Identifying Web Usability Criteria : The ' Scanmic 'Model," World Wide Web Internet Web Inf. Syst., vol. 44, 2001.

[29] E. Wurtz, "Intercultural communication on website: A cross-cultural analysis of web sites from high-context cultures and low-context cultures,” J. Comput. Commun., vol. 11, pp. 274-299, 2006.

[30] E. T. Hall, "The silent language," in The Silent Language, 1959, pp. 73-76.

[31] E. M. Rogers and W. B. Hart, "Edward T . Hall and The History of Intercultural Communication: The United States and Japan," Communication, vol. 24, no. 24, pp. 3-26, 2002.

[32] S. Nishimura, A. Nevgi, and S. Tella, "Communication Style and Cultural Features in High / Low Context Communication Cultures : A Case Study of Finland, Japan and India," Helsinkifi, 
no. Lc, pp. 783-796, 2008.

[33] A. Gamsriegler, "High-context and law-context communication styles," Int. Immunol., vol. 26, no. June, p. NP, 2005

[34] J. Hooker, "19 Cultural Differences in Business Communication," Handb. Intercult. discourse Commun., vol. 29, p. 389, 2012.

[35] L. Mohd Salleh, "High / Low Context Communication : The Malaysian Malay Style High / Low Context Communication: The Malaysian Malay Style," Assoc. Bus. Commun. Annu. Conv., no. April, pp. 1-11, 2005.

[36] H. Nurdiyanto, R. Rahim, S. Nurarif, and M. Ramadhan, "Enhanced pixel value differencing steganography with government standard algorithm," in Proceeding - 2017 3rd International Conference on Science in Information Technology: Theory and Application of IT for Education, Industry and Society in Big Data Era, ICSITech 2017, 2018, vol. 2018-Janua. 